\title{
EMPOWERING INDONESIAN FEMALE DOMESTIC WORKERS
}

\author{
Rosita Tandos \\ State Institute for Islamic Studies (IAIN) Syekh Nurjati Cirebon \\ Email: rtandos2014@gmail.com
}

\begin{abstract}
Transnational domestic work is a billion dollar business that has a great impact to economic development of both sending and receiving countries. In fact, women are the main actors of this business that involve multiple stakeholders from governmental and non-governmental institutions and private sectors. Realizing the importance position of the women is necessary to enhance policies, programs and services that will bring positive impact to their lives. Islamic community development studies might provide religious perspective that integrates with other disciplines of studies such as social work, public policy and analysis, and social development. It might contribute ideas, principles and values used for improving social and economic conditions of transnational domestic workers. Therefore, it is necessary to extend the concept of Dakwah from communication (dakwah bil-lisan) into creating social action and movement (dakwah bil-hal) for attain extensive social change.

Pekerjaan rumah tangga transnasional adalah bisnis miliar dolar yang memiliki dampak yang besar bagi pembangunan ekonomi kedua negara pengirim dan penerima. Bahkan, perempuan merupakan aktor utama bisnis ini yang melibatkan berbagai pemangku kepentingan dari lembaga pemerintah dan nonpemerintah, dan sektor swasta. Menyadari posisi pentingnya perempuan perlu meningkatkan kebijakan, program dan layanan yang akan membawa dampak positif bagi kehidupan mereka. Studi pengembangan masyarakat Islam dapat memberikan perspektif agama yang terintegrasi dengan disiplin keilmuan lain dari berbagai disilin kelimuan seperti kerja sosial, kebijakan publik dan analisis, dan pembangunan sosial. Pengembangan masyarakat Islam dapat menyumbangkan ide-ide, prinsip-prinsip dan nilai-nilai yang digunakan untuk meningkatkan kondisi sosial dan ekonomi pekerja domestik-transnasional. Oleh karena itu, perlu untuk memperluas konsep Dakwah dari komunikasi (dakwah bil lisan-) dalam menciptakan aksi sosial dan gerakan (dakwah bil-HAL) untuk mencapai perubahan sosial yang luas.
\end{abstract}

Keywords: Transnational domestic work, female migrant domestic workers, community development, and social change. 


\section{A. Introduction}

Gender equality for creating prosperity and social justice is a concept that has been emphasized in development process. These ideas also have been mandated in al-Quran and Hadits Nabi saw., aim to create al-maslahah mursalah (public welfare) that has great impact to the life of society. To support the process, social responsibility is a key to accelerate it and create fundamental change and innovation.

Women are among components of society that has an important role in family and community lives. Their role has been described in Islam as madrasatun ula or the first school for children, and partner for husband to build a harmony in the family life. In addition, al-Quran and Hadits describe role models offemale figures who lead a prosperous country, called Queen of Balqis;and female-Islamic figures such as Ummul Mukminin Khadijah r.a. and Sitti Aisyah r.a.. Both of them are mentioned as the main figures in Islamic teaching or dakwah and the development process at the beginning period of the history of Islam.

Such notion and inspirable stories might lead to the need for improving the role of women. However, current modern life still leaves a question of to what extent muslimah and Indonesian women as an element of society that play important roles in family and development process of the country. Statistical data from BPS in 2010 shows that the percentage of the women in Indonesia almost the same with their counterparts. In fact, women mostly live in the rural areas that are far from adequate public amenities. Inequality and injustice have been maintained also by patriarchal-cultural system, which is commonly embedded in the life of individual, families and communities.

Furthermore, the cultural system has been intertwined with global economic system that put more pressures to developing and indebted countries. Structural adjustment programs (SAPs) have been determined by the international financial bodies such as World Bank and IMF throughout their policies such as privatization and transnational work. Applying neoliberalism, these institutions emphasize efficiency, high price in accessing public services, and more competition for gaining decent job. They tend to ignore welfare values of equality, equity, security and liberty in their policies and programs.

The impact of cuts in social services and unemployment is devastating. Women are highly affected by structural adjustment programs and many women end up going overseas in search of new opportunities. Many women are forced to turn to subsistence food production, informal work, migration, 
and prostitution. Additionally, the women who cross borders illegally may enter unregulated and often irregular work situations. ${ }^{1}$

The majority of opportunities through legal channels of migration is in male-dominated sectors and put women at a great disadvantage. Sending countries tightly control migration processes, but simultaneously allow private employers and recruiting agencies to operate 'unchecked' by regulation or inspection. ${ }^{2}$ Therefore, migration officials are known to falsify the documents of female migrant workers. The recruitment prerequisites are just on paper and cannot be seriously implemented. ${ }^{3}$

Reflecting to such realities, this paper will provide a description of problems examined by women locally and globally, and explore more possibilities for Islamic studies such as Islamic community development and social welfare to improve their roles to transform the life of people and create social justice. To this end, this paper highlights some points of current issues of Indonesian women who live on rural areas and have to leave their villages for working domestically overseas due to insufficient public assistances, supports, and services. Although this paper will be focused more on the issue of female migrant domestic workers, its discussion might be possibly applied to other situations examined by other marginalized groups.

\section{B. Problems}

Female migrant domestic workers are called as 'heroes of foreign exchange' for their financial contribution to family and this country, but they often sacrifice themselves for uncertainty and lack of protection and empowerment. Because of their legal position, both domestic workers who work in their own country and those who migrate abroad remain vulnerable to violation of their rights at all stages of the work cycle. For example, in Singapore, more than one hundreds Indonesian domestic workers have died during past five years, most of them falling escaped or ran away from their employers. ${ }^{4}$ The discussion of the issue of empowering Indonesian female

${ }^{1}$ Ehrenreich, B\& Hochschild. Global women: Nannies, maids, and sex workers in the new economy (Canada: Owl Books, 2004), p.34-35. See also, Satterthwaite, Satterthwaite, M. Intersecting protection, migrating women: Using human rights law to empower women migrant workers. Marginalization, Discrimination and Equality Series, Volume 6,5-42.

2 Raharto, A. Indonesian Female Labor Migrants: Experiences Working Overseas. (Jakarta: Indonesian Institute of Sciences, 2002), p.26-29.

3 Silvey, R. Transnational Migration and the Gender Politics of Scale: Indonesian domestic workers in Saudi Arabia. Tropical Geography, Volume 25, p.141-155.

${ }^{4}$ International Labor Organization. Protecting the rights of migrant workers: A shared responsibility.(Geneva: ILO,2009). 
migrant domestic workers aims to gain a broad perspective that least includes three main points that are explored throughout this paper: 1)Factors that affect the women's decisions to work overseas, 2) Religious and CommunityBased Institutions' contributions, 3) Working for the issue of transnational domestic work (using community development approach)

\section{Factors Affecting Decision to Working Overseas}

The New Order regime, under the second president of the Republic of Indonesia (President Suharto), started to send female migrant domestic workers out of the country in 1984. In the intervening years, the Indonesian government sends laborers overseas as a part of the country's development plan, mainly to alleviate poverty. Remittances sent home by migrant workers are important not only for the workers, but also to the country as a source of revenue. ${ }^{5}$

During the period of 1999 to 2004, the Indonesian government sent 2.8 million workers abroad and collected US\$91 million in foreign exchange. The number increased significantly to US $\$ 3.4$ billion in 2006 and US $\$ 53.36$ billion in 2011.This income is among the largest revenue for the country. However, the policy of sending female domestic workers contributes to factors that affect women socially, culturally, economically, and politically.

The profile of domestic workers overseas varies significantly by country, while the differences between domestic workers overseas and those varies significantly by country and calls attention to the need to distinguish push and pull factors for these different groups. There are five main factors in relation to the life of rural Indonesian women existing at the individual, family, community, society, and state levels; and associated female migrant domestic worker.

First, data from the Statistical Bureau of Indonesia show that the rural population is $119,321,070$ and the number of poor people living in these rural areas is 14.84 million. Women living in rural areas of Indonesia are still considered lack accessibility to public services, education, and trainings to develop knowledge, skills and experiences. Such condition often forces them to work as migrant domestic workers. Only 5 percent of the female migrant workers graduated from university, and only 36 percent graduated from

5.Silvey, Transnational Migration and the Gender Politics of Scale, p.4-5. 
junior and senior high school. The remaining 59 percent either finished or dropped out of elementary school. ${ }^{6}$

A study of Cianjur regency (West Java province of Indonesia) found that the majority of female migrants from this area who migrate illegally had only completed primary school and never attended special training related to their job overseas. A small number of them could write, read, and speak Indonesian fluently, but only in a local dialect (Sundanese). As the women lack education and knowledge, they had difficulty in understanding the contents of work and their rights and duties mentioned in the work contract. ${ }^{7}$

For several of Indonesia's ethnic groups, women have traditionally played a significant role in generating household income through productive work both within and outside the household. ${ }^{8}$ However, performance on gender equality scales in Indonesia still lags behind other developing countries. In 2002, a combination of women's lower literacy rate $(86 \%$ as opposed to $94 \%$ for men) fewer mean years of schooling (6.5 years compared to 7.6 years for men), and smaller share of earned income (38\% compared to $62 \%$ for men) worked to counteract advances in life expectancy for women (Data from World Bank in 2010).

A second factor arises from cultural values emphasizing children's responsibilities for supporting their family. In traditional and patriarchal families, priority is given to educating the boys because of their broader responsibilities as children, and as future husbands and fathers. This inherent attitude in a community gives rise to female domestic helpers who are uneducated and unskilled, and who must therefore accept lower-paying jobs. Such social constructions have negative effects on women's options and outcomes, and yet they are also 'praised' as heroes for supporting their families and country with their income.

A third factor comes from the combination of high rates of unemployment and intense competition for desirable and skilled jobs. The unemployment numbers in Indonesia rose from 10.3 million in 2003 to 11.19 million in 2005, and the number of Indonesian migrant workers leaving the country increased at the same time. This condition was intensified by the economic crisis of 1998.

6 International Labor Organization, UsingIndonesian law to protect and empower Indonesian migrant workers,(Geneva: ILO, 2006), p.1-15.

${ }^{7}$ Bell, D. \& Piper, N, Justice for migrant workers?. The case of foreign domestic workers in Hong Kong and Singapore. In Kymlicka, W. \& He, B. (eds), Multiculturalism in Asia, (Oxford: Oxford University Press, 2005).

8 Williams, L., \& Labonte, R. Empowerment for Migrant Communities: Paradoxes for Practitioners (Canada: Taylor and Francis, 2007), p. 25. 
Briar-Lawson mentioned factors that influence immigration of workers. It was defined as "local and national constraints, changing circumstances, social problems, and barriers related to employment and social and cultural exclusion". ${ }^{9}$ Network factors also affects significantly to the flow of people to gain employment. Having a network with sponsors, families and friends who migrate earlier has influenced female domestic workers to follow the same effort. Lastly, keep factors are dealing with cultural differences and preferences, and abandoning infants and children and elders that keep female migrant workers going back home.

The pull factors refer also to economic reason was mentioned as well by Briar, which is caused by active recruitment and demand structures of transnational domestic work. It occurs as countries with a highly educated and skilled workforce often have difficulty finding local workers to fill low payingjobs. Consequently, host countries often adopt immigrant friendly policies to entice female domestic workers. ${ }^{10}$ This creates extensive opportunities to work overseas either legally or illegally, and results in immigration becoming an option for women to improve their economic conditions. Additionally, stories told by previous female migrant domestic workers influence them to immigrate. The message they receive is that successful workers can provide education for their children, fulfill their family's needs, and building a new family home. ${ }^{11}$

The fifth and final factor is political in nature. It is illegal recruitment of migrant workers, supported by two immigration issues, namely illegal immigration procedures and a lack of border protection between Indonesia and other neighboring countries. The long-term and undocumented Indonesians migrated to Malaysia is arguably the second largest illegal migration, following of immigrants crossing the Mexican border into the United States. Additionally, Indonesian governmental policies and regulations for sending and protecting immigrants have not effectively eliminated the existing problems, and are still criticized for a lack of attention, commitment and control.

9 Briar, K.H., \& Lawson, H.A,Expanding partnerships for vulnerable children, youth, and families. (Virginia: The Council of Social Work Education, Inc., 1996), p.35-36.

10 Albin, E. \&Mantouvalou, V,The ILO convention on domestic workers: From the shadows to the light. (Virginia: UCL Labor Rights Institutes, 2012), p.67.

${ }^{11}$ Anggraeni, D, Dream Seekers: Indonesia Women as Domestic Workers in Asia. (Jakarta: Equinox Publishing, 2006), p.41-42. 


\section{Contributions of Religious and Community-Based Institutions}

Efforts at protecting and empowering female migrant domestic workers have also been conducted by non-governmental organizations (NGOs). Silvey in her study conducted in 2004 found that NGOs in both sending and receiving countries are taking up the issue of protection and empowerment to support foreign migrant workers. Based on these findings, transnational linkages among NGOs and researchers should be encouraged to facilitate exchange of information and knowledge.

Riker explained that NGOs in Indonesia have existed since the 1980s where they network and share experience, take collective actions, and express their concerns and interests. The development of these networks and coalitions was extremely important for political change. Therefore, efforts aiming to protect the female workers' rights should emphasize collaboration between sending and receiving countries. ${ }^{12}$ Cooperation among local, national, and international bodies is extremely needed to address structural problems through producing and implementing policies that reflect the needs and interests of Indonesian female domestic migrants. ${ }^{13}$

In Asia, NGOs and community-based organizations (CBOs) have initiated the first step for immigration cooperation. This is due to the absence of state involvement and public ignorance of migrant workers' welfare and rights. The organizations help to channel services and support female migrant workers in several destination countries. ${ }^{14}$

Additionally, faith-based organizations (FBOs), including Catholic churches, are important institutions that provide supports to female migrant domestic workers. The FBOs in Malaysia, Singapore and Lebanon provide places or shelters for the female workers from Philippines, Sri Lanka, Ethiopia and India. ${ }^{15}$ Local mosques and Buddhist temples in Singapore design specific programs to welcome migrant domestic workers and provide physical and psychological assistances. These FBOs help connect women with embassies and lawyers, and provide shelter, health care, and engagement with the government.

12 Dominelli, L. Feminist social work theory and practice.(New York: Palgrave Macmillan, 2002), 51.

13 Novirianti, D, District legislation and access to justice: A case study of female migrant workers in Cianjur 2011.

14 Bell, D. \& Piper, N, Op.Cit, p. 1-22.

15 Ibid, 11. 
For future interventions, Islamic organizations and institutions have possible great contributions or challenges to enhance their program into assistances for female migrant domestic workers. Empowerment programs might be developed and enhanced running from individuals into community, organizations and policy programs. An organization that manage zakah funds, for example, could develop a capacity building program like providing knowledge and skills so that the women can work professionally and survive in a proper way while living overseas. The next part discusses efforts that apply community development perspective and public policy analysis to create better life of female migrant domestic workers.

\section{E. Working for The Issue of Transnational Domestic Work}

Given the fact that globalization impacts so many systems including in the filed of transnational domestic work, it is important that new discourses and theories of academic analysis and respective disciplinary frames incorporate all interventions for helping female migrant domestic workers. In addition, the challenges of a paradigm shift are necessary to reorder the organizing principles of social life and world order. ${ }^{16}$

Islamic community development education at Dakwah faculty might integrate in the curriculum or study process on the discussion of gender issue that specially address the point of transnational domestic work. Furthermore, community development studies and programs are necessary to implement the concept of working with people, and figure out efforts to enhance social welfare of the women. There are at least four main steps that might be implemented to address the issue of transnational domestic work:

\section{Empowering Youth and Families}

Women's expertise in taking care of households' responsibilities is extensively channeled by the global labor market. Family members pressure them to work as migrant domestic workers. Kinship ideology and kinship groupings become powerful social forces that pressure daughters and young women to live overseas.

This asymmetrical power relationship often results in young girls and women being the least powerful people in the family, controlled by family rules and kinship obligations. Hugo identified several areas in the family that are affected by migration. They are family structure and composition, family

16 Lawson, M.A, A case study of school-linked, collective parent engagement. American Educational Research Journal, Volume 20, 2011, p.1-34. 
headship, marriage and divorce, intergenerational and intra-familial relationships, care of children and the aged, the economic situation of the family, the role and status of women and power relationships in the family. ${ }^{17}$

On the other hand, feminist economists raise an important issue of family matters in transnational domestic work. Children of both female workers and employers couldn't access completely their own mothers. The children spend less time with their own mothers because the mothers are working, often taking care of someone else's children. ${ }^{18}$ Furthermore, while the domestic workers migrate to solve the problems of social reproduction of women in the richer countries, their own families are forced to overcome the problems in her absence. The domestic workload of the migrant female worker is shifted to other women and girls in the family. This scheme of responsibility leads to the increase in unpaid female labor with consequences, such as the educational and employment deprivation of the unpaid female workers that leads to the transmission of female poverty. ${ }^{19}$

At the family level, domestic workers ease the women's burden of housekeeping. However, their presence often creates tension in the family due to the jealously of female employers and sexual advances of the male employers. Problems still continue after finishing their contract. In some cases, returning women experience trauma and are socially rejected because of unexpected pregnancies due to being raped by their male employers. These women face the shame of bearing children outside wedlock, and suffer as victim blaming by their own family and friends. In addition, other situations faced by the female migrant workers are their husbands taking mistresses and/or their children no longer know them. Those are human costs for which no amount of money can compensate.

Considering the drawbacks associated with transnational domestic care, family intervention programs should integrate women's needs of protection from abuses and violations that are often faced by illegal women workers who work overseas under illegal procedures. ${ }^{20}$ Diverse family cultures may have differences in structure regarding communication style, family hierarchy and power structure, and the family's relationship to the dominant external culture. ${ }^{21}$ Therefore, cultural sensitivity should also be taken into account to

17 Heyzer N., \&Nijeholt G.L.A \&Weerakoon, N. The Trade in Domestic Workers: Causes, Mechanisms and Consequences of International Migration. International Review of Victimology: Zed Books), p.125.

18 Ibid, 77-78.

${ }^{19}$ Esim \& Smith, Gender and migration in Arab States: The case of domestic worker, 2004.

20 International Labor Organization, Op.Cit, p.1-24.

21 Chang, G. Disposable domestic: Immigrant women workers in the global economy. (Cambridge: South End Press, 2000), p.301. 
improve services for the women, especially for service of a short-term nature in which cultural beliefs of clients are considered and integrated.

Improving the family's roles to prevent women from the influence of illegal agencies or sponsors can support protection and empowerment efforts. However, family support programs have not become concerns of the Indonesian government yet. Therefore, future policy changes should support low-income families of migrant workers and consider them as experts and partners. Policy makers should aim to gain more comprehensive understanding of the issue and enhance protection, empowerment for the women and their contributions to family lives, especially for caring for children as a future investment in the family.

\section{Supporting Groups and Community}

Employers often say that the socio-cultural background of female domestic workers is often identified as a barrier to the adjustment process. The training and preparation process is not sufficiently designed to help the women to cope with issues such as cultural shock and adjustment.

Resilience of the women usually works as the main and immediate solution to tackle daily problems. Therefore, the women workers who socialize with other Indonesian workers tend to discuss their problems and gather with their Indonesian friends. However, the majority of Indonesian female migrant domestic workers in Malaysia are not allowed to call back home, communicate with other Indonesian migrant workers, or socialize with their employers. ${ }^{22}$ Consequently, there are significant cases of runaway female workers. They feel unsatisfied with the protection from the agency or sponsor and the problems are frequently not resolved due to employers keeping their immigration documents.

Runaway workers often go to the Indonesian Embassy's shelters or stay temporarily with friends in their contacts. In Jeddah (Saudi Arabia), there are numerous runaway migrant workers who are reported living under the bridge of the city or at 'unoccupied land' together with other workers who face similar violated conditions. To respond to such condition, the Indonesian government has gradually sent back the workers who become homeless in the host country.

In some destination countries, the women's movement provides service-oriented groups for transnational domestic workers. Yeoh and Annadhuri described how women's organizations in Singapore assist and

22 Orange, G., Seitz., V., Information dissemination needs of Indonesian migrant domestic workers in Malaysia. Journal of Southeast Asian Research, 2012, p.1-16. 
create 'social space' for the women to meet their compatriots in similar employment situations. ${ }^{23}$ These organizations ensure the women's voices to be heard and provide advocacy-oriented groups to fill 'the vacuum in areas' which the government has left unattended or not done enough. All of these three points are main areas in which social workers might play an important role through improving policies, programs, and services that consider the female workers as key partners and experts, not just as passive service recipients .Furthermore, collaboration between academics, NGOs, and individual migrants should aim to improve the condition of migrant workers and protective legal mechanisms.

\section{Collaborative and Partnership With All Stakeholders}

As one of the reasons of female domestic workers to work overseas is socio-economic reason, community development programs might be offered to alleviate poverty, social exclusion, and social isolation. The idea of Muhammad Yunus (a Nobel Peace Prize recipient) from Bangladesh might be adopted to enhance rural and poor women so that they become financially independent, skilled, and contribute to the life of family. Moreover, natural and human resources and other social capital (values, norms and principles) existing in the life of community need to be developed and diversified to be local excellent products. This economic program might be used to recruit local human resources, improve their capabilities, and increase income to communities. Such efforts could provide an alternative to the rural women for leaving at home, but still be able to contribute financially to the life of family.

On the other hand, schools and universities or other educational institutions, and non-governmental organizations (NGOs) play important roles to fill the gaps that cannot fully addressed by the governments. For instance, Islamic Educational Institutions might help students to avoid failed or drop out from basic education levels or tertiary education; even they could help families and communities, and then support the learning process for the future success of students. This effort might also create a safe place for the women to improve their capabilities before deciding to work overseas. They will migrate with sufficient knowledge, skills and social supports. In other words, civic society should be involved to actively control the processes of working overseas.

Furthermore, Islamic community development programs specifically and other applied sciences need to apply 'single-loop learning process', seeing students as object of teaching process, focusing on internal function and

${ }^{23}$ Piper, N, Gender and Migration Policies in Southeast Asia and East Asia: Legal Protection and Socio-Cultural Empowerment of Unskilled Migrant Women, (Canberra: the Australian National University,2004), p. 82. 
ignoring the important role of families and communities. Furthermore, the educational institutions need to develop double-loop learning, enhance dialog and partnership with families and communities, even apply triple-loop learning process that acknowledge other components of society to achieve desirable outcomes and create fundamental changes. ${ }^{24}$

The genuine collaboration and active partnership in planning, implementing and evaluating programs have to involve all stakeholders, especially female domestic workers. All of them are responsible to create effective changes. This cooperation and supporting networks become a crucial point to avoid overlapping activities or programs, and address the basic and complex problems faced by female migrant domestic workers. One-stop services need to be provided as integrated assistances and services available for women, families, and communities. It provides a mean to voice their needs and aspiration, considering them as partners or experts to the problems they face daily. Furthermore, illegal procedures and agencies that recruit female domestic workers should be controlled and eliminated to ensure prosperity and justice in the life of female domestic workers.

\section{International Legal Standard for Female Domestic Labors}

The ILO (2012) emphasizes two points that should be considered when reforming labor laws to enhance the protection of domestic workers. First, one must understand migrant domestic labor's magnitude, the characteristics of domestic workers and their employers, and the prevailing patterns and arrangements under which domestic workers is performed (living in or living with arrangements); and second, there must be an analysis of the existing national laws to identify the legal provisions that may already be applicable to domestic workers.

The challenges for creating health and safety workplace come not only from receiving countries that often do not consider household helpers as workers. The host countries still exclude domestic workers from protection under their national labor codes, and do not provide them with optional protection under any other national law. For sending countries, the issues of corruption, lack of institutional coordination between the local and national governments, and lack of negotiation with the host country's governments are the vital issues that need to be seriously addressed.25

${ }^{24}$ Lawson, T, Sending Countries and the Rights of Women Migrant Workers: the Case of Guatemala, (Boston: Harvard Law School, 2005).

25 Loveband, A, Positioning the product: Indonesian migrant women workers in contemporary Taiwan. Working Papers Series, Volume 43,2003, p. 13. 
The implementation of a binding contract and policy change between the sending and receiving governments, as well as between the employer and employee should also be conducted. For instance, Said discussed that the officials of the United Arab Emirates are in the process of preparing a contract to be binding internally.26 To ensure the rights of all parties, the contract should state clearly all conditions under which a domestic worker has to work, the rights and obligation of the employees and their employers. This should be explained to both parties before the women start to work.

Standards for recruiting, preparing, sending, living, working, and finishing of contracts for foreign female domestic workers are needed with guidelines to eliminate issues like psychological and physical violations. Strict regulations are also needed to stop agency illegal practices with the ability for the women to file lawsuits if the agency fails to perform their obligation of protecting the women's rights. This means that agencies that work with domestic workers should be reachable and responsible for unexpected situation experienced by the women.

Developing knowledge and skills of foreign domestic workers is another crucial element of protection and empowerment program. For instance, the Philippines Embassy and labor office becomes an ideal model for a sending country. They have become more active in solving problems. They also provide trainings in basic skills like literacy, computing, and cooking as well as workers' rights. Such effort helps the female domestic migrant workers to change their status from 'unskilled workers' to 'skilled workers', which will affect the protection under the international labor (the ILO) law and regulation. ${ }^{27}$ Both efforts of policy change are needed to create health and safe environment for female foreign domestic workers.

\section{F. Conclusion}

Exploring the complex socio-cultural, economic and political meanings and specific interventions available for protecting and empower-ring the female workers can bring a greater clarity and implications drawn for future interventions of protection and empowerment. At the top level, the governments are expected to apply an integrated and integrity approach in understanding and finding solutions to transnational domestic work problems, and other problems examined by marginalized or vulnerable groups. Through

26 Varia, N,'Sweeping Changes?'A Review of Recent Reforms on Protections for Migrant Domestic Workers in Asia and the Middle East, (New York: Human Right Watch,2010), p. 56.

${ }^{27}$ Sabban\& Smith.Women migrant domestic workers in the United Arab Emirates. (The ILO publication, 2001). 
this process, communities are positioned as partners and experts to explore situations, problems and solutions. They should access to sufficient information and proper public facilities before asking them to be responsible to work.

Educational, religious organizations, and other non-governmental institutions are among key elements that can help achieve the expected outcomes and changes. Islamic boarding schools and universities, for instance, could improve their roles to educate, empower and develop people capabilities. Additionally, religious and community leaders have to contribute actively to address problems since they have been cultivated relationship with their communities. They have been kept in touch daily with communities, knowing strengths and weaknesses owned by communities. Individuals, families also have a vital contribution to support the process of change and bring justice for all of the family's members, especially for girls and women. All attempts for creating gender equality and social justice will help family life to improve their prosperity and welfare condition. 


\section{REFERENCES}

Ehrenreich, B\& Hochschild. Global women: Nannies, maids, and sex workers in the new economy (Canada: Owl Books, 2004), p.34-35. See also, Satterthwaite, Satterthwaite, M. Intersecting protection, migrating women: Using human rights law to empower women migrant workers. Marginalization, Discrimination and Equality Series, Volume 6

Raharto, A. Indonesian Female Labor Migrants: Experiences Working Overseas. (Jakarta: Indonesian Institute of Sciences, 2002)

Silvey, R. Transnational Migration and the Gender Politics of Scale: Indonesian domestic workers in Saudi Arabia. Tropical Geography, Volume 25

International Labor Organization. Protecting the rights of migrant workers: $A$ shared responsibility.(Geneva: IL0,2009)

International Labor Organization, UsingIndonesian law to protect and empower Indonesian migrant workers,(Geneva: ILO, 2006)

Bell, D. \& Piper, N, Justice for migrant workers?. The case of foreign domestic workers in Hong Kong and Singapore. In Kymlicka, W. \& He, B. (eds), Multiculturalism in Asia, (Oxford: Oxford University Press, 2005).

Williams, L., \& Labonte, R. Empowerment for Migrant Communities: Paradoxes for Practitioners (Canada: Taylor and Francis, 2007)

Briar, K.H., \& Lawson, H.A,Expanding partnerships for vulnerable children, youth, and families. (Virginia: The Council of Social Work Education, Inc., 1996)

Albin, E. \&Mantouvalou, V, The ILO convention on domestic workers: From the shadows to the light. (Virginia: UCL Labor Rights Institutes, 2012)

Anggraeni, D, Dream Seekers: Indonesia Women as Domestic Workers in Asia. (Jakarta: Equinox Publishing, 2006)

Dominelli, L. Feminist social work theory and practice.(New York: Palgrave Macmillan, 2002)

Novirianti, D, District legislation and access to justice: A case study of female migrant workers in Cianjur 2011.

Lawson, M.A, A case study of school-linked, collective parent engagement. American Educational Research Journal, Volume 20, 2011 
Heyzer N., \&Nijeholt G.L.A \&Weerakoon, N. The Trade in Domestic Workers: Causes, Mechanisms and Consequences of International Migration. International Review of Victimology: Zed Books)

Esim \& Smith, Gender and migration in Arab States: The case of domestic worker, 2004.

Chang, G. Disposable domestic: Immigrant women workers in the global economy. (Cambridge: South End Press, 2000)

Orange, G., Seitz., V., Information dissemination needs of Indonesian migrant domestic workers in Malaysia. Journal of Southeast Asian Research, 2012

Piper, N, Gender and Migration Policies in Southeast Asia and East Asia: Legal Protection and Socio-Cultural Empowerment of Unskilled Migrant Women, (Canberra: the Australian National University,2004)

Lawson, T, Sending Countries and the Rights of Women Migrant Workers: the Case of Guatemala, (Boston: Harvard Law School, 2005).

Loveband, A, Positioning the product: Indonesian migrant women workers in contemporary Taiwan. Working Papers Series, Volume 43, 2003

Varia, N,'Sweeping Changes?'A Review of Recent Reforms on Protections for Migrant Domestic Workers in Asia and the Middle East, (New York: Human Right Watch,2010)

Sabban\& Smith. Women migrant domestic workers in the United Arab Emirates. (The ILO publication, 2001) 